\title{
PLECTRANTHUS AMBOINICUS (LOUR.) SPRENG SEBAGAI BAHAN PANGAN DAN OBAT SERTA BIOAKTIVITASNYA
}

\author{
Marina Silalahi \\ marina.silalahi@uki.ac.id \\ Universitas Kristen Indonesia
}

\begin{abstract}
The Plectranthus amboinicus was a succulent herb belonging Lamiaceae that has long been used by humans as food and medicine. The utilization of plants as food and medicine related to secondary metabolite content. The writing of this article is based on literature review of various books and scientific articles obtained on line or off line. The leaves and stems of P. amboinicus contains essential oils that produce flavor and aroma, so that its used as a vegetable, seasoning, and maternal postpartum menu. The bioactivity of $P$. ambonicus extract has activity as anti microbial, anti cancer, and hepaprotective. The P. amboinicus is potentially developed as a culinary ingredient as a natural food preservative.
\end{abstract}

Keywords: Plectranthus amboinicus, essential oil, antioxidant, and antimicrobial.

\begin{abstract}
ABSTRAK
Plectranthus amboinicus merupakan herba sukulen dari famili Lamiaceae yang telah lama dimanfaatkan oleh manusia sebagai bahan pangan dan obat. Pemanfaatan tumbuhan sebagai bahan pangan dan obat berhubungan dengan kandungan metabolit sekundernya. Penulisan artikel ini didasarkan pada kajian literatur dari berbagai buku dan artikel ilmiah yang diperoleh secara on line maupun off line. Daun dan batang $P$. amboinicus mengandung essensial oil yang menghasilkan cita rasa dan aroma yang khas digunakan sebagai sayur, bumbu masak, dan menu ibu paska melahirkan. Uji bioaktivitasnya dari ekstrak $P$. ambonicus memiliki aktivitas sebagai anti mikroba, anti kanker, dan hepaprotektif. Plectranthus amboinicus sangat potensial dikembangkan sebagai bahan kuliner sebagai pengawet makanan alami.
\end{abstract}

Keywords: Plectranthus amboinicus, essential oil, antioksidan, dan antimikroba. 
Silalahi, Plectranthus Amboinicus (Lour.) Spreng sebagai Bahan Pangan dan Obat serta Bioaktivitasnya

\section{PENDAHULUAN}

Plectranthus

amboinicus

merupakan salah satu spesies dari famili Lamiaceae yang sebelumnya dikenal sebagai Coleus ambonicus (Wadikar dan Patki 2016), oleh masyarakat Indonesia dikenal dengan daun jinten (de Padua et al. 1999). Plectranthus amboinicus sinonim dengan Coleus amboinicus, Coleus aromaticus, dan Coleus carnosa (de Padua et al. 1999), sehingga dalam berbagai artikel ilmiah ada beberapa nama yang digunakan terumata Plectranthus amboinicus, Coleus ambonicus, dan Coleus aromaticus. Oleh karena itu nama ilmiah tumbuhan tersebut sering ditemukan berbeda antara satu artikel ilmiah dengan artikel ilmiah lainnya.

Wadikar dan Patki (2016) menyatakan bahwa daun Coleus aromaticus telah lama digunakan sebagai bahan makanan diberbagai negara seperti Amerika Selatan, Filipina, Indonesia, Afrika, India, dan negara-negara lainnya di Asia Tenggara. Oleh etnis Batak khususnya sub-etnis Batak Simalungun di Sumatera Utara memanfaatkan daun Plectranthus amboinicus sebagai salah satu menu utama bagi ibu yang menyusui karena diyakini dapat meningkatkan air susu ibu dan membuat ibu lebih sehat (Damanik 2009). Selain memanfaakan sebagai bahan pangan masyarakat lokal Indonesia juga memanfaatkan daun $P$. ambonicus sebagai obat luka, jamur kulit, demam, asma, batuk dan sakit kepala (de Padua et al. 1999), dalam bentuk ramuan maupun dalam bentuk tunggal. Wadikar dan Patki (2016) melaporkan bahwa $P$. amboinicus dimanfaatkan sebagai antimikroba, antioksidan. Bagi masyarakat lokal India P. Ambonicus digunakan sebagai obat demam malaria, hepatopathy, ginjal dan vesikel calculi, batuk, asma kronis, cegukan, bronkitis, anthelmintik, kolik, dan kejang (Hullatti dan Bhattacharjee 2011).

Pemanfaatan daun $P$. ambonicus sebagai obat maupun bahan pangan mengakibatkan tanaman tersebut mudah ditemukan di pekarangan. Plectranthus amboinicus merupakan tanaman sukulen aromatik dengan batang dan daun berdaging tebal. Batang 
memiliki banyak percabangan dengan aroma yang khas yang dihasilkan oleh daun (Wadikar dan Patki 2016). Aroma yang dihasilkan daun dan batang $P$. ambonicus membuatnya cocok digunakan sebagai salah satu bahan utama bumbu untuk daging dan ikan, yang berfungsi untuk membantu menyamarkan bau (Wadikar dan Patki 2016), dan sangat potensial dikembangkan menjadi kuliner.

Pemanfaatan tumbuhan baik sebagai bahan pangan maupun obat berhubungan dengan kandungan senyawa kimianya atau yang dikenal juga sebagai metabolit sekunder. Tumbuhan yang digunakan sebagai sayur merupakan tumbuhan yang kaya akan vitamin maupun serat sedangkan tumbuhan yang digunakan sebagai obat merupakan tumbuhan yang memiliki senyawa bioaktif yang berfungsi untuk menyembuhkan. Carvacrol dan timol merupakan komponen utama yang bertanggung jawab terhadap cita rasa pada P. ambonicus (Wadikar dan Patki 2016). Walaupun penelitian tentang manfaat $P$. ambonicus telah banyak dilakukan, namun tulisan konprehensif mengenai kandungan metabolit dan pemanfaatan sebagi baha pangan maupun sebagai obat masih terbatas. Artikel ini akan menjadi salah satu sumber potensi pengembangan $P$. ambonicus sebagai bahan pangan yang menyehatkan maupun sebagai dan obat.

\section{METODE}

Tulisan ini didasarkan pada kajian literatur baik secara online dan offline. Berbagai buku maupun artikel ilmiah yang telah dipublikasi dikaji kemudian sintesakan sesuai dengan tujuan penulisan artikel.

\section{PEMBAHASAN}

1. Plectranthus amboinicus (Lour) Spreng

Famili Lamiaceae milik genus yang penting secara komersial seperti Plectranthus, Salvia, Ocimum, dan Mentha. Plectranthus L'Her memiliki sekitar 200 spesies (de Padua et al. 1999) - 300 spesies (Retief 2000) merupakan genus yang banyak terdistribusi di daerah tropis dan subtropis dunia lama (old world) terutama Afrika dan sekitar 15 
Silalahi, Plectranthus Amboinicus (Lour.) Spreng sebagai Bahan Pangan dan Obat serta Bioaktivitasnya

spesies merupakan tumbuhan asli (native) di kawasan Malesiana. Plectranthus amboinicus merupakan salah satu genus Plectranthus yang telah lama dimanfaatkan sebagai obat maupun bahan pangan oleh berbagai etnis di Indonesia maupun negara lain dan bahkan telah tercatat di Ayurveda (catatan pengobatan di India). Nama Plectranthus berasal dari bahasa Yunani (Greek) yaitu plectron yang berarti terdorong seperti taji (spur) dan anthos yang berarti bunga berbentuk taji yag terdorong (spur-shaped flowers) dari genus ini (Stearn 1992).

Plectranthus amboinicus

(Lour.) Spreng memiliki nama sinonim Coleus ambonicus Lour. (1790), Coleus aromaticus Benth. (1830), Coleus carnosa Hassk. (1842) (de Padua et al. 1999), merupakan herba menahun dengan siklus hidup 3-10 tahun dan juga merupakan tumbuhan asli Indonesia (Lukhoba et al. 2006; de Padua et al. 1999). Vernacular name Plectranthus amboinicus antara lain: country borage, Indian borage
(Inggris), daun jinten (Indonesia), ajeran (Sunda), daun kucing (Jawa), bangun-bangun (Malaysia), suganda (Tagalog) (de Padua et al. 1999) dan torbangun (Batak Simalungun) (Damanik 2009), terbangun (Batak Karo) (Silalahi et al 2015), dan bangun bangun oleh Batak Toba (Silalahi 2014).

Plectranthus amboinicus memiliki tinggi $100-120 \mathrm{~cm}$, tidak memiliki umbi, daun bulat telur melebr, berbentuk orbicular atau reniform, daun tebal dan berdaging. Bunga tersusun vertisilaster terdapat di bagian terminal. Kelopak subequally dengan 5 gigi, mahkota panjangnya 8-12 $\mathrm{cm}$ berwarna merah muda hingga biru, halus. Tumbuh dengan baik hingga ketinggan 1500 m dpl (de Padua et al. 1999) (Gambar 1). Permukaan atas dan bawah daun memiliki trikoma dan permukaan atas memiliki kutikula. Trikoma berbentuk uniseriate, multicellular dengan acute dibagian apex, bagian basal trikoma melebar, yang dibangun oleh 2-3 sel (Hullatti dan Bhattacharjee 2011). 


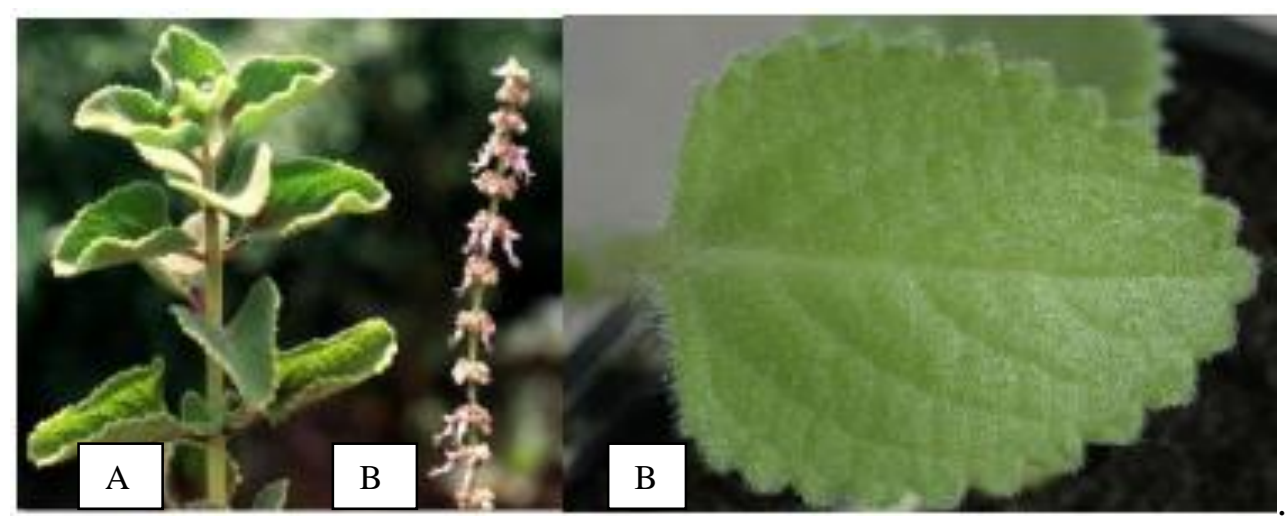

Gambar 1. Habitus dan daun Plectranthus amboinicus Pillai et al. (2011). A. habitus; B. Pembungaan; C. Daun

\section{KANDUNGAN METABOLIT}

\section{Plectranthus ambonicus}

Tumbuhan menghasilkan

berbagai metabolit primer dan metabolit sekunder. Metabolit primer merupakan metabolit yang dihasilkan dari proses metabolime primer seperti karbohidrat, protein, lemak dan asam nukleat. Metabolit primer merupakan metabolit yang dibutuhkan tumbuhan untuk pertumbuhan dan perkembangan, sedangkan metabolit sekunder yang dimanfaatkan untuk pertahanan terhadap lingkungan. Dalam proses metabolisme primer seperti proses metabolisme glukosa dihasilkan berbagai senyawa antara seperti fofoenol piruvat, eritrosa 4 fosfat, piruvat dan fosfogliseratyang menjadi prekusor dalam biosintesis metabolit sekunder (Taiz dan Zeiger 2006).

Tumbuhan mensintesis metabolit primer relatitif lebih besar konsentrasinya dibandingkan dengan metabolit sekunder. Walaupun konsentrasi metabolit sekunder relatif kecil dalam tumbuhan, namun jenisnya sangat dan sangat bervariasi antara satu tumbuhan dengan tumbuhan lainnya, bahkan dalam satu spesies bervariasi tergantung pada faktor internal dan eksternal (Taiz and Zeiger 2006). Metabolit yang dihasilkan oleh tumbuhan dimanfaatkan oleh manusia untuk berbagai tujuan. Karbohidrat, protein maupun lemak yang dihasilkan oleh tumbuhan oleh 
Silalahi, Plectranthus Amboinicus (Lour.) Spreng sebagai Bahan Pangan dan Obat serta Bioaktivitasnya

manusia dimanfaatkan sebagai bahan pangan, sedangkan metaboli sekunder biasanya dimanfaatkan sebagai obat, pewarna, dan insektisida.

\section{Plectranthus ambonicus} merupakan salah satu tumbuhan yang dimanfaatkan manusia sebagai bahan pangan. Di India, daun $P$. aromaticus ditambahkan dengan kelapa (Cocos nucifera), cabai merah (Capsicum annum), daun ketumbar (Corium sativum), dan daun kari (Murraya koenigii) daun digunakan untuk persiapan chutney (sambal dari buahbuahan) (Wadikar dan Patki 2016). Masyarakat lokal etnis Batak di Sumatra utara memanfaatkan daun $P$. ambonicus sebagai makanan utama bagi ibu pasca melahirkan (Damanik 2009). Pemanfaatan P. ambonicus sebagai bahan pangan berhubungan dengan kandungan nutrisinya seperti tertulis pada Tabel 1 (Arumugam et al. 2016).

Tabel 1.

Kandungan nutrisi pada Plectranthu ambonicus (Arumugam et al. 2016)

\begin{tabular}{ll}
\hline Senyawa & Kandungan \\
\hline Protein & $0,6 \%$ \\
Vitamin & $0,03 \%$ \\
asam askorbat & $0,00008 \%$ \\
Thiamin & \\
Mineral & $0,158 \%$ \\
Kalsium & $0,016 \%$ \\
Fosfor & $0,138 \%$ \\
Kalium & $0,0047 \%$ \\
Natrium & $0,088 \%$ \\
Magnesium & \\
Logam & $0,262 \%$ \\
Besi & $0,0003 \%$ \\
Zinc & $0,00012 \%$ \\
Copper & $0,000022 \%$ \\
Chromium & $0,31 \%$ \\
Serat yang terlarut & $1,56 \%$ \\
Serat yang tidaklarut & $0,00092 \%$ \\
Asam phytic & $0,2 \%$ \\
Oksalat terlarut & \\
\hline
\end{tabular}


Plectranthus amboinicus

merupakan salah satu jenis tumbuhan yang digunakan untuk meningkatkan air susu ibu oleh etnis di Sumatera Utara (Damanik 2009; Hasibuan 2014). Secara empirik pada etnis Batak P. ambonicus merupakan menu utama pada ibu pasca melahirkan dengan membuatnya seperti gulai sayur dengan menambahkan daging ayam sebagai komponen tambahan.

Selain dimanfaatkan sebagai bahan pangan $P$. ambonicus juga dimanfaatkan sebagai obat. Pemanfaatan tumbuhan sebagai bahan obat pada umumnya berhubungan dengan kandungan metabolit sekundernya. Metabolit sekunder merupakan metabolit yang dihasilkan dari proses metabolisme sekunder. Plectranthus ambonicus mengandung berbagai metabolit sekunder seperti tanin, saponin, flavonoid, glikosida steroid, poliuronida (Asiimwe et al. 2014; Sathasivam dan Elangovan 2011), alkaloid, glikosida jantung, terpenoid, dan flavonoid (Sathasivam dan Elangovan 2011). Senyawa phenolik utama pada $P$. ambonicus adalah asam rosmarinic $(6,160 \mathrm{mg} / \mathrm{g})$ dan diikuti dengan asam kafeat $(0,770 \mathrm{mg} / \mathrm{g})$, rutin $(0,324 \mathrm{mg} / \mathrm{g})$, asam gallic $(0,260 \mathrm{mg} / \mathrm{g})$, quercetin $(0,15 \mathrm{mg} / \mathrm{g})$, dan $p$-coumaric acid (0,104 mg/g) (Bhatt et al. 2013). Oleh karena itu $P$. ambonicus sangat potensial sebagai makanan maupun nutraceuticals (Bhatt et al. 2013).

Essensial oil atau yang sering juga disebut sebagi volatil oil merupakan golongan terpenoid yang banyak dikandung pada daun maupun batang $P$. ambonicus. Essensial oil yang dihasilkan oleh tumbuhan telah terbukti memiliki aktivitas sebagai anti mikroba (Silalahi 2016). Arumugam et al. (2016) menyatakal essensial oil yang terdapat di $P$. ambonicus dapat dikelompokkan menjadi 5 yaitu: monoterpene hydrocarbons, oxygenated monoterpenes, sesquiterpene hydrocarbons, oxygenated sesquiterpenes, oxygenated sesquiterpenes. Kandungan essensial oil yang terdapat pada P. ambonicus bervariasi dalam jenis, struktur maupun konsentrasinya. Essensial oil utama yang terdapat pada daun $P$. 
Silalahi, Plectranthus Amboinicus (Lour.) Spreng sebagai Bahan Pangan dan Obat serta Bioaktivitasnya

ambonicus adalah linalool (50,3\%), nerol asetat $(11,6 \%)$, geranyl asetat $(11,7 \%)$ dan carvacrol $(14,3 \%)$ (Asiimwe et al. 2014). Komposisi yang lain yang terkandung dalam $P$. amboinicus adalah $\beta$ - Myrcene, 4 Carene, $\gamma$-terpinene, $\beta$ - ocimene, $\beta$ -<smiles>CC1=CC[C@H]2[C@H](C1)C2(C)C</smiles><smiles>CC(C)C1CC2CCC1C2</smiles>

$\delta$-3-carene<smiles>CC(C)C1C=CC2CCC2C1</smiles>

$\alpha$-phellandrene<smiles>C=C/C(C)=C/CC=C(C)C</smiles>

Ocimene

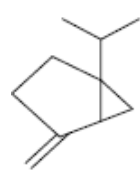

Sabinene

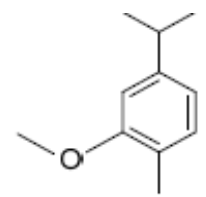

Methyl carvacrol<smiles>C=CC1CCC(O)C1OC</smiles>

Eugenol p-cymene<smiles>CCC1CCC(C)C(C)C1</smiles>

$\beta$-phellandrene<smiles>CC(C)c1ccc2c(c1)CCC2</smiles>

$\alpha$-terpinene

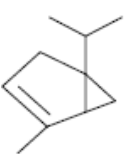

$\alpha$-thujene

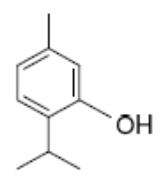

Thymol<smiles>CC(C)=CCC(C)(C)O</smiles>

Linalool<smiles>C=C(C)C1CCCCC1CC</smiles>

Limonene

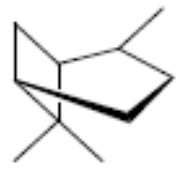

$\alpha$-pinene<smiles>CCc1ccc(C(C)C)cc1</smiles>

-terpinene<smiles>CC1(C)CCC(=O)C1(C)C</smiles>

Camphor<smiles>CC(C)=CC1CCC(C)C(C)C1</smiles>

Carvone<smiles>CC(C)=CCC(C)=CCO</smiles>

Gerniol<smiles>C=CC(=C)CCCC1=CCCC1</smiles>

B-myrcene

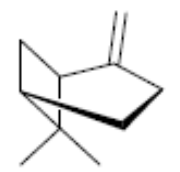

$\beta$-pinene<smiles>CC1=CC=C(C)CC1</smiles>

$\alpha$-terpineole<smiles>Cc1ccc(C(C)C)cc1O</smiles>

Carvacrol<smiles>CC12CCCC(C)(O1)C(C)(C)O2</smiles>

1,8-Cineole<smiles>COc1cc(C)ccc1C(C)C</smiles>

Thymol methyl 


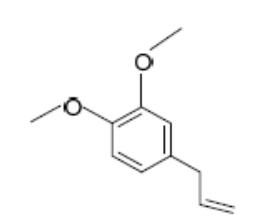

Methyl eugenol

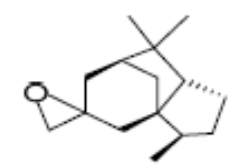

$\beta$-Cedrene epoxide

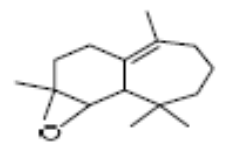

$\beta$-himachalene oxide

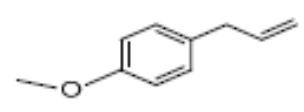

Methyl chavicol

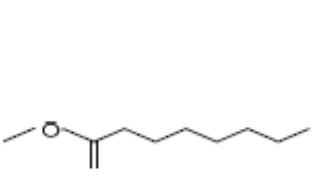

Methyl octanoate

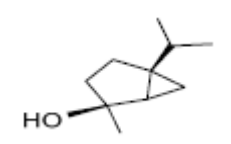

Trans-sabinene hydrate

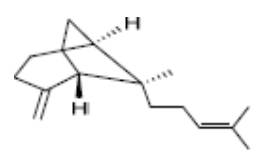

Trans- $\beta-$

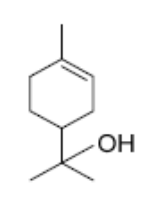

$\alpha$-terpineole

Terpinen-4-ol

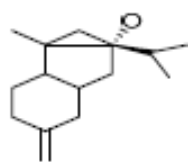

$\beta$-copaen-4- $\alpha$

ol

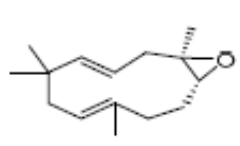

Humulene

oxide<smiles>CC(C)C1CC(C)C(C)C1</smiles>

Dyhidro

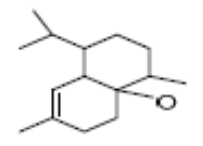

1-epi-cubenol

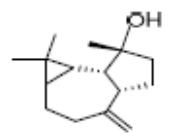

Spathulenol<smiles>CCOC(=O)C1C=CC=C1O</smiles>

Ethyl salicylate

carveol
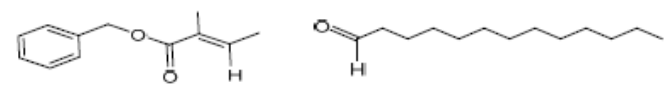

2-phenyl ethyl Tetradecanal tiglane

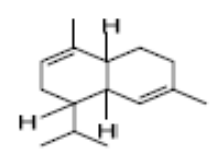

$\alpha$-amorphene

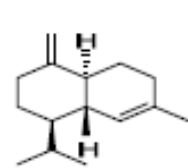

r-cadinene

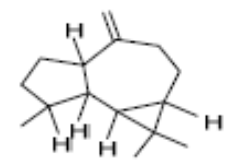

Aromadendrene

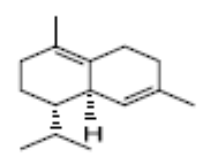

$\delta$-cadinene eter

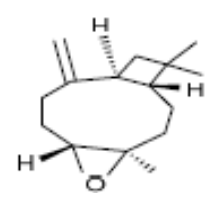

Caryophyllene oxide<smiles>C=C1CCC2CCC(C(C)(C)O)CC12</smiles>

$\beta$-eudesmol

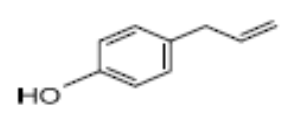

Chavicol<smiles>C/C=C\CCO</smiles>

(Z)-3-Hexen-1-ol<smiles>CCC(C)C1CCCC1C(C)C</smiles>

Thymol acetate

Trans- $\alpha$ - bergamotene
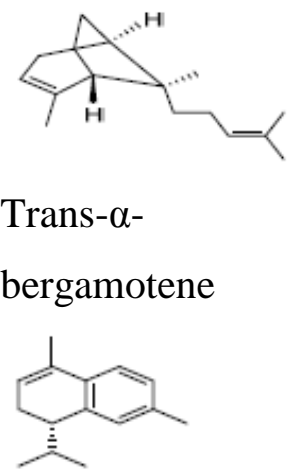

$\alpha$-calacarone 
Silalahi, Plectranthus Amboinicus (Lour.) Spreng sebagai Bahan Pangan dan Obat serta Bioaktivitasnya

bergamotene

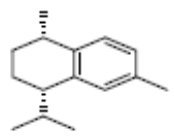

Cis-calamenene

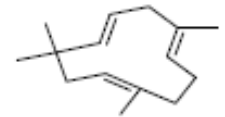

Humulene<smiles>CC(C)C1CCC(C)C23C=CCC12CC3</smiles>

$\alpha$-cubebene

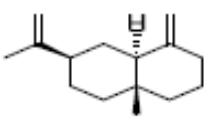

$\alpha$-selinene<smiles>C=C1CCC(C)=CC(C(C)C)CC1</smiles>

Germacrene D Patchoulene

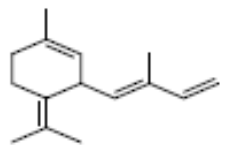

(E.Z)- $\alpha-$

Farnesene

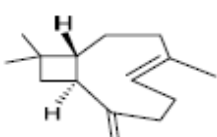

$\beta$-Caryophyllene
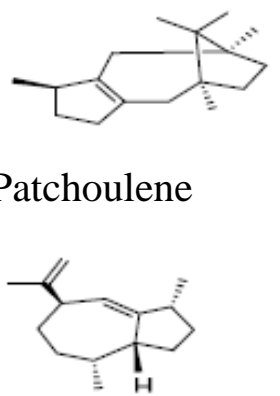

r-Gurjenene

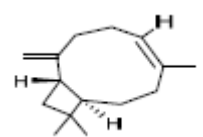

-Caryophyllene

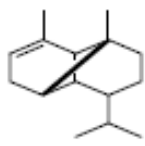

$\alpha$-copane

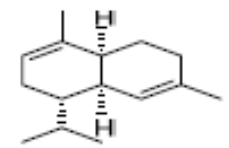

$\alpha$-muurolene<smiles>C=C1C=CC(CCC=C(C)C)(C(C)C)CC1</smiles>

$\beta-$

sesquiphellandrene

Gambar 2. Struktur essensial oil yang terdapat pada P. ambonicus (Arumugam et al. 2016)

Essensial oil P. ambonicus terutama diperoleh dari bagian daun dan batangnya, namun kadarnya bervariasi antara satu organ dengan organ lainnya dan juga bervariasi pada setiap musim. El-hawary et al. (2013) melaporkan bahwa kandungan essensial oil $P$. amboinicus yang dibudidayakan di Mesir bervarisi yaitu sebesar $0,12 \%$ $\mathrm{v} / \mathrm{b}$ berat basah di daun dan $0,13 \%$ di batang. Daun P. ambonicus mengandung: $\delta$-cadinene $\quad(18,66 \%$ pada musim semi) dan $(12,52 \%$ pada musim gugur), sedangkan $\beta$ caryophyllene $(12,65 \%)$ dan thymol $(8,75 \%)$ merupakan komponen utama pada musim dingin dan musim panas. Batang mengandung $\alpha$ humulene sebagai komponen utama pada musim dingin $(11,14 \%)$ dan summer $(12,70), \quad$ sedangkan,$\beta$ copaene-4- $\alpha$-ol $(9,37 \%)$ dan thymol $(13,02 \%)$ merupakan komponen utama pada musim semi dan gugur 
secara berurutan (El-hawary et al. 2013).

\section{MANFAAT}

Plectranthus

amboinicus merupakan tanaman obat yang telah dicatat di Siddha dan Ayurveda India (Thirugnanasampandan et al. 2015). Plectranthus amboinicus merupakan salah satu ramuan yang banyak ditemukan pekaranagan rumah khusunya di negara-negara di Asia (Wadikar dan Patki 2016), sangat potensial dalam nutraceuticals dan industri makanan. Berbagai peneliti melaporkan pemanfaatan $P$. aromaticus antara lain: antibakteri, aktivitas antimikroba (Wadikar dan Patki 2016) hepatopathy (Hullatti dan Bhattacharjee 2011) dan anti kanker (Thirugnanasampandan et al. 2015).

\subsection{ANTIMIKROBA}

Senyawa anti mikroba adalah senyawa yang menghambat pertumbuhan mikroorganisme (Elhawary et al. 2013). Plectranthus amboinicus telah dilaporkan memiki aktivitas sebagai anti bakteri (Wadikar dan Patki 2016; El-hawary et al. 2013) dan anti fungi (Wadikar dan Patki 2016; Manjamalai et al.
2012). Eesensial oil yang diperoleh dari daun $P$. amboinicus mampu menghambat pertumbuhan Klebsiella pneumoniae (Goncalves et al. 2012), Staphylococcus aureus (Manjamalai et al. 2012; Bhatt et al. 2013), Bacillus cereus, Escherichia coli, dan Yersinia enterocolitica (Bhatt et al. 2013), Bacillus subtilis (Bhatt dan Negi 2012; Astuti et al. 2012), Klebsiella planticola (Vanaja dan Annadurai 2013), Pseudomonas aeruginosa (Manjamalai et al. 2012; Astuti et al. 2012), S. aureus and $S$. thypi, (Astuti et al. 2012). Hambatan minimal konsentrasi (MIC) dan konsentrasi bakterisida minimal (MBC) dari esensial oil P. ambonicus sebesar $0,09 \pm 0,01 \%$. Daya hambat essensial oil tersebut sangat dipengaruhi oleh $\mathrm{pH}$ yaitu daya hambat pada $\mathrm{pH}$ netral atau basa dibandingkan dengan $\mathrm{pH}$ lainnya (Goncalves et al. 2012). Staphylococcus aureus, Bacillus cereus, Escherichia coli, dan Yersinia enterocolitica merupakan mikroba patogen yang mengakibatkan makanan menjadi busuk (Bhatt dan Negi 2012). Temuan menunjukkan potensi 
Silalahi, Plectranthus Amboinicus (Lour.) Spreng sebagai Bahan Pangan dan Obat serta Bioaktivitasnya

ekstrak etil asetat dan aseton daun $P$. ambonicus dapat digunakan sebagai biopreservatif (Bhatt dan Negi 2012).

Zona hambat essential oil dari P ambonicus terhadap bakteri Staphylococcus aureus dan Pseudomonas aeruginosa sebesar 31,6 mm lebih tinggi dari antibiotik standar yaitu cefepime $27 \mathrm{~mm}$ dan Gatifloxacin sebesar $\quad 26,6 \quad \mathrm{~mm}$ (Manjamalai et al. 2012). Selain menghambat pertumbuhan bakteri ternyata essensial oil dari $P$. ambonicus juga menghambat pertumbuhan jamur antara lain Candida albicans, C. parapsilosis dan C. tropicalis (Manjamalai et al. 2012). Zona hambat dari essensial oil $P$. amboniscus pada Candida albicans, C. parapsilosis dan C.tropicalis sebesar $15 \mathrm{~mm} 13.6$ dan $12 \mathrm{~mm}$ secara berturut turut atau lebih kecil dari antifungi standar fluconozole sebesar $17 \quad \mathrm{~mm}$ (Manjamalai et al. 2012).

\subsection{ANTIKANKER}

Kanker merupakan salah satu penyebab kematian yang paling tinggi, yang disebabkan oleh pembelahan sel yang tidak terkendali (Seca et al. 2018). Beberapa metabolit sekunder yag memiliki efek farmakologis seperti paclitaxel (taxol) yang berfungsi menghambat pembelahan sel oleh karena itu dapat digunakan sebagai obat kanker (Buyel 2017). Jenis metabolit sekunder lain yang diekstrak dari tumbuhan yang menunjukkan aktivitas anti kanker di antaranya pregnane glycosida (desmiflavaside D) dan alkaloids (mahanine) menghambat pertumbuhan sel kanker payudara dan sel kanker prostate secara berurutan.

Pemanfaatan Plectranthus amboinicus sebagai anti kanker telah dilaporkan oleh Hasibuan (2014), Thirugnanasampandan et al. (2015), Bhatt et al. (2013), dan Seca et al. (2018). Ekstrak n-hexane, ethylacetate metanol, dan ethanol dari Plectranthus amboinicus memiliki aktivitas cytotoxic terhadap sel HeLa dengan nilai IC50 sebesar $76.322 \mu \mathrm{g} / \mathrm{mL}, 143.291 \mu \mathrm{g} / \mathrm{mL}$, dan $88.997 \mu \mathrm{g} / \mathrm{mL}$ secara berurutan (Hasibuan 2014). Sitotoksisitas esensial oil P. ambonicus terhadap sel kanker payudara (MCF-7) dan sel kanker kolorektal (HT-29) dengan nilai IC50 masing-masing $53 \pm 0,01$ 
dan $87 \pm 0,01 \quad \mu \mathrm{g} / \mathrm{mL}$ (Thirugnanasampandan et al. 2015). Ekstrak Plectranthus amboinicus menunjukkan aktivitas antiproliferative melawan sel kanker dari cell lines: Caco-2, HCT-15, dan MCF-7 (Bhatt et al. 2013). Essensial oil yang menghambat pertumbuhan sel kanker adalah $\gamma$ - terpinene, $p$ cymene, $\beta$ - caryophyllene dan $\alpha$ humulene (Thirugnanasampandan et al. 2015).

\subsection{HEPATOPROTEKTIF}

Hati berperan merupakan salah satu organ penting pada manusia yang digunakan untuk detoksifikasi (Goldman dan Andrew, 2012). Berbagai bahan makanan maupun minuman seperti alkohol, zat pengawet atau pewarna makanan dan berbagai mikroorganisme dapat mengakibatkan kerusakan atau gangguan pada hati (Achliya et al. 2014). Kerusakan hati akan berdampak pada gangguan metabolisme pada tubuh manusia. Ahirwar dan Tembhre (2016) menyatakan bahwa pemberian ekatrak Coleus ambonicus sebesar $200 \mathrm{mg} / \mathrm{kg}$ berat badan pada tikus yang telah diinduksi $2 \mathrm{ml} / \mathrm{kg}$ seminggu sekali untuk jangka waktu 30 hari dengan karbon tetraklorida menunjukkan peningkatan alanine amino transferase (ALT), aspartate amino transferase (AST), alkaline phosphatase (ALP), acid phosphatase (ACP), total protein dan total bilirubin. Senyawa karbon tetraklorida merupakan senyawa yang mengakibatkan keruasakan hati pada tikus (Ahirwar dan Tembhre 2016). Hal tersebut menunjukkan bahwa ektrak etanol P. ambonicus bersifat hepatoprotektif, sehingga sangat potensial dikembangkan untuk mengobati ganguan hati. Pada pemberian ekstrak kasar P. ambonicus secara oral hingga dosis $10.000 \mathrm{mg} / \mathrm{kg}$ tidak menyebabkan kematian, namun dapat mengakibatkatkan nekrosis sel-sel hati dengan kemacetan umum di korteks ginjal, pneumonitis, dan peluruhan vili usus (Asiimwe et al. 2014). Ekstrak air P. amboinicus aman digunakan seperti yang ditunjukkan oleh nilai LD50 tinggi, tetapi harus digunakan dengan hatihati pada dosis tinggi (Asiimwe et al. 2014). 


\section{KESIMPULAN}

1. Daun dan batang $P$. amboinicus mengandung essensial oil yang menghasilkan cita rasa dan aroma yang khas digunakan sebagai sayur, bumbu masak, dan menu ibu paska melahirkan.

2. Kadar essesnsial oil pada $P$. amboinicus bervariasi dalam jenis dan kosentrasi antara satu organ dan organ lainnya dan sangat dipengaruhi oleh musim.

3. Uji bioaktivitasnya dari ekstrak P. ambonicus memiliki aktivitas sebagai anti mikroba, anti kanker, dan hepaprotektif. Plectranthus amboinicus sangat potensial dikembangkan sebagai bahan kuliner sebagai pengawet makanan alami.

\section{ACUAN PUSTAKA}

Achliya G.S., Wadodkar S.G., and Dorle A.K. (2004): Evaluation of hepatoprotective effect of Amalkadi Ghrita against carbon tetra chloride induced hepatic damage in rats.
Journal of

Ethnopharmacology $\quad 90$ : 229-232.

Ahirwar, P. and Tembhre, M. (2016). Hepatoprotective efficacy of Coleus amboinicus leaf extract on carbontetrachloride induced liver damage in Rats. Asian J. Exp. Sci., 30(1-2): 45-50

Arumugam, G., Swamy, M.K., and Sinniah, U.R. (2016). Plectranthus amboinicus (Lour.) Spreng: botanical, phytochemical,

pharmacological and nutritional significance. Molecules 21( 369): 1-26.

Asiimwe, S., Borg-Karlsson A.K., Azeem, M., Mugisha, K.M., Namutebi A., and Gakunga, N.J. (2014). Chemical composition and toxicological evaluation of the aqueous leaf extracts of Plectranthus amboinicus Lour. Spreng. International Journal of Pharmaceutical Science Invention 3(2): 1927.

Astuti, P., Sudarsono, S., Nisak, K., and Nugroho, G.W. (2014). Endophytic fungi isolated from Coleus amboinicus Lour exhibited antimicrobial activity. Adv Pharm Bull, 4(Suppl 2): 599-605.

Buyel, J.F. (2017). Biotechnology and Production of AntiCancer Compounds Springer International Publishing DOI 10.1007/978-3-319-538808_2: 39-56.

Bhatt, P., Joseph, G.S., Negi, P.S., and Varadaraj, M.C. (2013). Chemical composition and 
nutraceutical potential of indian borage (Plectranthus amboinicus) stem extract. Hindawi Publishing Corporation Journal of Chemistry, Article ID 320329, 7 pages http://dx.doi.org/10.1155/201 3/320329.

Bhatt, P. and Negi, PS. (2012). Antioxidant and antibacterial activities in the leaf extracts of indian borage (Plectranthus amboinicus). Food and Nutrition Sciences 3:146-152.

Damanik, R. (2009). Torbangun (Coleus amboinicus Lour): A Bataknese traditional cuisine perceived as lactagogue by Bataknese lactating women in Simalungun, North Sumatera, Indonesia. J Hum Lact. 25(1): 64-72.

de Padua, L.S., Bunyapraphatsara and Lemmens, R.H.M.J. (1999). Plant resources of South-East Asia no 12(1). Backhuys Publishers, Leiden.

El-hawary, S.S., El-sofany, R.H., Abdel-Monem, A.R., Ashour, R.S., and Sleem, A.A. (2013). Seasonal variation in the composition of Plectranthus amboinicus (Lour.) Spreng essential oil and its biological activities. American Journal of Essential Oils and Natural Products 1(2): 11-18.

Goncalvesa, T.B., Braga, M.A., de Oliveiraa, FF.M., Santiago, G.G.M.P. Carvalho, CB.M., Cabrala, P.B., Santiago, T.D.M., Sousa, J.S., Barros, E.B., do Nascimentog, R.F.,
Nagao-Dias, A.T. (2012). Effect of sub inihibitory and inhibitory concentrations of Plectranthus amboinicus (Lour.) Spreng essential oil on Klebsiella pneumoniae. Phytomedicine 19: 962- 968.

Goldman, L. and Andrew, I. (2012). Goldman's Cecil Medicine, Twenty - Fourth Edition, US Elsevier Health Bookshop, 1(8): Chapter 149.

Hasibuan, A.P.A.Z. (2014). Hacytotoxic effect of nhexane, ethylacetate and ethanol extracts of Plectranthus amboinicus, (Lour.) Spreng.) on HeLa and vero cells lines. International Journal of PharmTech Research 6(6): 1806-1809.

Hullatti, K.K., and Bhattacharjee, P. 2011. Pharmacognostical evaluation of different parts of Coleus amboinicus lour., Lamiaceae. Pharmacognosy Journal 3(24): 39-44.

Lukhoba, C.W., Simmonds, M.S.J., Paton, A.J. (2006). Plectranthus: A review of ethnobotanical uses. Journal of Ethnopharmacology 103: 1-24.

Manjamalai, A., Alexander, T. and Grace, V.M.B. (2012). Bioactive evaluation of the essential oil of plectranthus amboinicus by GC-MS analysis and its role as a drug for microbial infections and inflammation. Int $J$ Pharm Pharm Sci, 4(3): 205-211

Pillai, P.G., Suresh, P., Aggarwal, G., Doshi, G., and Bhatia, V. (2011). Pharmacognostical standardization and toxicity 
profile of the methanolic leaf extract of Plectranthus amboinicus (Lour) Spreng. Journal of Applied Pharmaceutical Science 01 (02); 2011: 75-81

Retief, E. (2000). Lamiaceae (Labiatae). In seed plants of Southern Africa; Leistner, O.A., Ed.; National Botanical Institute: Cape Town, South Africa: $323-334$.

Seca, A.M.L., and Pinto, DCG.A. (2018). Plant secondary metabolites as anticancer agents: successes in clinical trials and therapeutic application. Int. J. Mol. Sci. 19(263): 1-22.

Silalahi, M. (2014). Etnomedisin Tumbuhan Obat pada Etnis Batak Sumatera Utara dan Perspektif Konservasinya [Disertasi]. Program Pascasarjana Biologi, FMIPA, Universitas Indonesia: xxviii+165 hlm.

Silalahi, M., Nisyawati, Walujo, E.B., Supriatna, J., and Mangunwardoyo, W., 2015. The local knowledge of medicinal plants trader and diversity of medicinal plants in the Kabanjahe traditional market, North Sumatra, Indonesia. Journal Ethnopharmacology 175, 432-443.
Silalahi, M. (2018). Essensial oil pada kemangi (Ocimum basilicum L.). Jurnal Prolife 5(2): 557-566.

Stearn, W.T. (1992). Stearns Dictionary of Plant Names for Gardeners: A Handbok on the Origin and Meaning of the Botanical Names of Some Cultivated Plants; Cassell: London, UK, 1992.

Taiz, L. and Zeiger, E. (2006). Plant Physiology. Sinauer Associates, Inc, Sunderland: xxvi $+764 \mathrm{hlm}$.

Thirugnanasampandan, R., Ramya, G., Gogulramnatha, M., Jayakumar, R., and Kanthimathi, M.S. (2015). Evaluation of cytotoxic, DNA protecting and LPS induced MMP-9 down regulation activities of Plectranthus amboinicus (Lour) Spreng essential oil. Pharmacognosy Journal 7(1): 32-36.

Wadikar, D.D., and Patki, P.E. (2016). Coleus aromaticus: a therapeutic herb with multiple potentials. $J$ Food Sci Technol. 53(7): 2895-2901.

Vanaja, M. and Annadurai, G. (2013). Coleus aromaticus leaf extract mediated synthesis of silver nanoparticles and its bactericidal activity. Appl Nanosci 3: 217-223. 